\title{
On Written Corrective Feedback in L2 Writing
}

\author{
$\mathrm{Xu} \mathrm{Shao}^{1,2}$ \\ ${ }^{1}$ School of Foreign Langauge, Shaanxi Normal University, Xian, China \\ ${ }^{2}$ School of Foreign Langauge, Qinghai Normal University, Xining, China \\ Correspondence: Xu Shao, School of Foreign Language, Shaanxi Normal University, Xian, China. Tel: \\ 86-138-9281-7096. E-mail: 13997204636@163.com
}

Received: November 5, 2014 Accepted: December 15, 2014 Online Published: February 13, 2015

doi:10.5539/elt.v8n3p155 URL: http://dx.doi.org/10.5539/elt.v8n3p155

\begin{abstract}
Truscott (1996) questions the practicability of grammar correction, and he believes that written corrective feedback (WCF) is not only a waste of time, but even harmful to the students as well. This has led to a great deal of discussion and research on WCF in second-language (L2) writing. Ferris (1999) is the representative opponent of Truscott's point of view, who argues that WCF should not be abandoned in that it can improve the accuracy of L2 learners' writing. Many empirical studies have been conducted and the results support Ferris' view that WCF is useful in promoting the development of L2 writing. This paper gives a literature review from a dichotomy perspective of WCF.
\end{abstract}

Keywords: written corrective feedback, L2 writing, accuracy, second language acquisition

\section{Introduction}

Written corrective feedback (WCF) in L2 writing, otherwise known as grammar correction (e.g., Truscott, 1996, 1999) or written error correction, has been much studied and hotly debated in applied linguistics over the past 18 years. Truscott (1996) questions the practicability of grammar correction, and he believes that Grammar Correction (GC) is not only a waste of time, but even harmful to the students as well. This has led to a great deal of discussion and research on GC in second-language (L2) writing. Ferris (1999) is the representative opponent of Truscott's point of view, who argues that GC should not be abandoned in that it can improve the accuracy of L2 learners' writing. Many empirical studies have been conducted and the results support Ferris' view that GC is useful in promoting the development of L2 writing, and the field seems to take Ferris' (1999) generalization that students believe in GC and want to receive it for granted. Although researchers have extensively studied the effectiveness of different types of GC usually in terms of L2 development as gagued by pretests and postests in both laboratory and classroom settings, little is known about students' perceptions of GC in their English writing. Despite from the rare existing studies, most of them take Ferris' (1999) stance for granted by testing which type of GC is more effective than others based on students' perceptions, it would certainly be premature to formulate any conclusions about this topic, more researches are needed on investigating students real perceptions over the effectiveness of GC.

The essence for Truscott (1996) stance is that most L2 writing teachers accept GC as a necessary activity without any critical thinking of whether this approach is effective or not. Grammar Correction has no place in writing courses and should be abandoned. The reasons are: (a) Research evidence shows that Grammar Correction is ineffective; (b) this lack of effectiveness is exactly what should be expected, given the nature of the correction process and the nature of language learning; (c) grammar correction has significant harmful effects; and (d) the various arguments offered for continuing it all lack of merit (1996, pp. 328-329).

In response to Truscott (1996), Ferris (1999) pointed out Truscott (1996)'s stance "grammar correction has no place in writing courses and should be abandoned" (p. 328) is quite premature and overly strong. Ferris ideas can be summarized in the following aspects: surveys of student opinion showed their consistent affirmation on the importance of GC; professors feel that students' linguistic errors are bothersome and affect their overall evaluation of students papers, writing instructors should not ignore their students' linguistic difficulties; the absence of any feedback or strategy training will ensure that many students never take seriously the need to improve their editing skills and they will not have the knowledge to edit even when they do perceive its importance. 
As a response to Truscott's work, a substantial amount of research over the two decades or so has focused specifically on the effectiveness of written feedback (e.g. Lalande, 1982; Robb et al., 1986; Semke, 1984; Ferris \& Helt, 2000; Bitchener, 2008; Chandler, 2003; Ellis 2007, Russel \& Spada, 2006; Sheen, 2007). On the contrary, a few studies have been proven on the ineffectiveness of GC (Kepner, 1991; Polio et al., 1998; Truscott, 1996, 1999).

\section{Feedback and Classification (McNulty, 2007)}

\subsection{Feedback Definitions}

In order to understand current-trend in research related to feedback provision, it is important to examine different ways recent researchers have defined this process and its effectiveness in the learning process. This section of this literature review will provide a narrative that will provide various definitions of feedback and highlight differences and similarities between different researchers.

In 1977, Kulhavy defined feedback as "any of the numerous procedures that are used to tell a learner if an instructional response is right or wrong" (p. 211). For example, providing a student with the right answer would be a simple example to illustrate this definition of feedback. In addition to providing the definition of feedback, Kulhavy (1977) also argued that the quality and effectiveness of feedback is influenced by "presearch availability," a term that describes availability of the information necessary for the learning to occur. In other words, the learning tends to be more successful if "research availability" is low, which forces a learner to search for necessary information or read through it in order to locate correct answers instead of just copying them down. For example, if a student is just provided with the correct answer, the learning is suggested to be less successful compared to learning scenarios where learners have to actively search for the information. The same effect was later confirmed by Bangert-Drowns et al. (1991), who also suggested that "research availability" strongly influences the results of feedback provision. When "research availability" is low, students become an active learner, which goes back to the cognitivism theory that suggest that learning is only then effective when learners actively interact with the environment around them.

Other researchers have also provided broad definitions of feedback similar to the one provided by Kulhavy (1977). These definitions describe feedback as the information provided to the learner regarding his/her actions with the intent to assist the learner to either reinforce correct responses or to search for replacement for the incorrect ones (Hattie et al., 1996). Kulhavy (1977) assert that "successful instruction nearly always includes performance related feedback" (p. 3). In other words, feedback that is provided to a learner should include information about actions for the learner to take in order to determine the correct performance. Hattie et al. (1996) argue that feedback is one of the most powerful variables that impacts achievement and that it needs to be used extensively in education. They continue by providing the example of homework assignments. Hattie et al. (1996) suggest that homework with feedback is more useful than homework without feedback. However, Hattie et al. (1996) caution that feedback is only useful and effective, when it provides students with information specific to their actions and that will help them to better understand ways to improve their performance.

Kulhavy and Stock (1989) divide feedback into two categories: verification and elaboration. Verification is just a confirmation of the correct or incorrect answer, whereas elaboration provides learners with clues to guide them towards correct choice (Kulhavy \& Stock, 1989). The discussion of these two definitions are important because according to Hattie et al. (1996), most researchers are in agreement that in order for feedback to be effective (learning achievement), it needs to include both types of information. In other words, it needs to provide the learner with the information whether their answer is correct or incorrect, and if it is incorrect, it needs to provide them with enough information and guidance to discover the correct answer.

\subsection{Feedback as an Educational Tool}

Feedback research has a long history (e.x., Kulhavy \& Stock, 1989; Pressey, 1926; Trowbridge \& Carson, 1932). In 1926, Pressey designed a testing machine, which provided learners with an immediate response to whether their answers were correct or incorrect. In 1932, Trowbridge and Carson conducted an experiment where they tested subjects who were blindfolded and were asked to draw lines precisely four inches long. The subjects were divided into two groups (one was provided with verbal feedback; another one was not). Each group was given 100 attempts to complete the task. The researchers found that the group that received feedback on their performance, improved over the time, whereas the group that didn't receive feedback, showed no signs of improvement (Trowbridge \& Carson, 1932). Both studies show that even 80 years ago, researchers were attempting to examine the complex issue of feedback provision and its effectiveness in terms of learning. 
In order to understand various theories of feedback, it is important to understand the history of feedback, which has transformed from a behaviorist to cognitive perspective over time. Kozma and Bangert-Drowns (1987) noted that behaviorists viewed feedback more as a stimulus-response process, where the purpose of feedback was to stimulate a person to repeat a correct answer. This principle served as the basis for programmed instruction. Cognitive perspective, which evolved in response to the behaviorist approach, is more than just a stimulus-response process. Proponents of the cognitive perspective, view feedback as a process that assists learners by providing them just enough information to self control and self regulate their own learning (Bangert-Drowns et al., 1991). In other words, cognitivism started to view the learner as an active participant of the learning process. Cognitivism described the learning process as an interaction between a learner and the environment, stressing the importance of feedback as a crucial component of a successful learning process in this environment (Bangert-Drowns et al., 1991). The main delineation between behaviorist and cognitive approaches to feedback provision is in their perspective on the role of the learner in the learning process. The proponents of behaviorist theory view learners as passive receivers of feedback, whereas proponents of the cognitive perspective view learners as active participants in the learning process.

\subsection{Feedback and Its Functions in Second Language Acquisition}

Feedback, as a reactive form of form-focused-instruction (Lightbown \& Spada, 1994), has been claimed to be effective in promoting noticing, and thus conductive to second language learning (Mackey \& Philp, 2003; Philp 2003; Sheen, 2007; Trofimovich, Ammar, \& Gatbonton, 2007). However, it has also undergone a substantial amount of discussion over the past three decades regarding its explicitness and implicitness, its effectiveness on second language acquisition, the type of evidence it provides, and more importantly, the learning mechanism it triggers (Ammar \& Spada, 2006; Ellis \& Sheen, 2006; Ellis, Loewen, \& Erlam, 2006; Lyster, 2004b; Lyster \& Mori, 2006; Sheen, 2007). The detailed discussion of the term feedback begins with a look at its classification.

The study of feedback in second language acquisition experienced an evolution similar to feedback in general (e.g., Henderickson, 1978). For decades, language acquisition researchers studied effective methods for responding to learner errors. According to Henderickson (1978), second language acquisition history progressed from grammar translation days, when errors indicated improperly learned knowledge to the present, when errors are considered a natural part of the learning process indicating that the learner is in the process of creating a new language constitution. Although the error perception has differed at various periods of time, common focus among researchers has always been on observing error treatment in various classrooms and trying to determine better ways to respond to learner' errors. Henderickson (1978) compiled a comprehensive overview of the research related to error treatment and also suggested that the learners should discover errors and be more actively involved in the error correction process, which in turn could help them to retain new knowledge in a long-term memory.

While there are still disparate views of error correction treatments, it appears that researchers generally agree that there should be more than one approach to error correction, however, it is still unclear, which type of teacher feedback results in most successful immediate learner uptake. This part of the literature review focuses on feedback types and student uptake. It also presents an overview of various studies that have been conducted in this area with emphasis on similarities and differences between the findings in terms of feedback effectiveness in a foreign language classroom.

Corrective feedback is defined as a response to a learner's utterance that contains error (Ellis et al., 2006). Like sin, error is to be avoided and its influence overcome, but its presence is to be expected ... the principal way of overcoming it is to shorten the time lapse between the incorrect response and the presentation once more of the correct model (p. 56).

\subsection{Feedback and Classification}

Researchers in second language acquisition tend to differentiate feedback in terms of how explicit or implicit it is. In the case of implicit feedback, there is no clear indication that an error has been committed or where the errors are, whereas in explicit feedback types, there is such an indication (Ellis et al., 2006). Implicit types of feedback often take the form of recasts, defined by Long (1996) as:

A reformulation of all or part of a learner's immediately preceding utterance in which one or more non-target like (lexical, grammatical, etc.) items are replaced by the corresponding target language form, and where, throughout the exchange, the focus of the interlocutors is on meaning not language as an object (p. 2).

However, this dichotomous classification of feedback can be problematic. Research shows that depending on contexts (cf. Sheen, 2004) as well as characteristics of recasts (such as linguistic targets, length, and number of 
changes), recasts can also be quite explicit, for example, bu adding intonation and stress (Egi, 2007a).

Explicit types of feedback can also take a variety of forms according to different scholars. Ellis et al. (2006) claim that explicit feedback takes the form of either explicit correction, in which the response clearly indicates that the learner produced an erroneous utterance, or meta-linguistic feedback, defined as "comments, information, or questions related to the well-formed of the learner's utterance" (Lyster \& Ranta, 1997, p. 47). Others have ope-rationalized explicit feedback in various ways. For example, Carroll (2001) and DeKeyser (1993) distinguished between explicit feedback that involved some specification of the nature of the error and explicit feedback that provides more detailed meta-linguistic knowledge (Sheen, 2007).

Lyster (2002) questioned the reliability of comparing the effects of feedback in accordance with degrees of explicitness, based on his observation that it is self-repair which results from the illocutionary force of prompts rather than from their explicitness that contributes to second language development. He distinguishes recasts from prompts, which consists of clarification requests, repetitions, meta-linguistics clues, and elicitation of the correct form. He draws such a distinction based on the idea that, while recasts provide learners with the target forms, prompts may engage learners in a deeper level of processing because they require the learner to retrieve the target form themselves. This view of categorizing different types of feedback is further illustrated in the following section.

Lyster's and Ranta's (1997) have divided corrective feedback into seven categories: explicit; recast; metalinguistic feedback; elicitation; repetition; clarification and translation (see Table 1).

Table 1. The definitions of corrective feedback

\begin{tabular}{|c|c|}
\hline $\begin{array}{l}\text { Types of corrective } \\
\text { feedback }\end{array}$ & Definitions \\
\hline Explicit & $\begin{array}{l}\text { feedback is in the form of telling the student that the response was incorrect and providing } \\
\text { the correct response or other direct information, expecting the uptake to occur, based on } \\
\text { this information) A feedback technique that involves a teacher simply providing a student } \\
\text { with the correct answer Gives information about the incorrect utterance (such as provision } \\
\text { of a rule) }\end{array}$ \\
\hline Recast & $\begin{array}{l}\text { feedback in the form of teacher restating the student's error and omitting it) A more } \\
\text { implicit feedback technique that involves the teacher's reformulation of all or part of a } \\
\text { student's utterance, minus the error Provision of correct response orally }\end{array}$ \\
\hline $\begin{array}{l}\text { Metalinguistic } \\
\text { feedback }\end{array}$ & $\begin{array}{l}\text { Feedback that involves the teacher indicating to the student that there is an error, but not } \\
\text { providing him/her with the correct response) Involves a teacher making comments or } \\
\text { indicating to the student that there is an error in the language output (ex., Can you find an } \\
\text { error?) Provision of indirect information }\end{array}$ \\
\hline Elicitation & $\begin{array}{l}\text { feedback that involves the teacher strategically pausing when getting to the student's error } \\
\text { and providing him/her with clues for self correction) A feedback type when teachers ask } \\
\text { for completion of their own sentence by pausing and allowing students to correct } \\
\text { themselves; they may also ask questions to elicit correct form and help students to } \\
\text { reformulate an ill-formed utterance Gives part of correct response or established cue in a } \\
\text { different medium }\end{array}$ \\
\hline Repetition & $\begin{array}{l}\text { Feedback that involves the teacher repeating a student's mistake by using intonation) The } \\
\text { type of the feedback that involves a teacher repeating wrong utterance highlighting it with } \\
\text { intonation Repeating of the incorrect utterance with rising intonation }\end{array}$ \\
\hline Clarification & $\begin{array}{l}\text { Feedback that indicates that student's utterance was not understood and asks that the } \\
\text { student reformulate it. }\end{array}$ \\
\hline Translation & Feedback that involves the detailed correction processes \\
\hline
\end{tabular}

\section{The "WCF Is Effective" Hypotheses (Yang, 2008)}

\subsection{The Role of Input and Output in SLA}

In second language acquisition research, there has been an on-going debate over the role of positive evidence 
and negative evidence as well as the effect of input and output on language learning.

\subsubsection{Definition of Types of Evidence}

There is a general consensus in both L1 and L2 literature that language learners are exposed to two types of input, namely, positive evidence and negative evidence. According to Gass (2003), positive evidence refers to the input that consists of a set of well-formed sentences, speech samples that available from the spoken language and from the written language. These speech samples are referred to as the most direct means that learners have available from which they can form linguistic hypotheses. Positive evidence has been noted to be the most obviously necessary requirement for both L1 and L2 acquisition (Gass, 2003).

Negative evidence refers to the type of input that is provided to learners concerning the incorrectness of an utterance. This might be in the form of explicit or implicit information. Based on Long and Robinson's (1998) taxonomy, negative evidence can be composed of two types: pre-empty (occurring before an actual error - as in a classroom context), i.e. Pre-planned, or reactive. If reactive, it can be explicit or implicit. Explicit negative evidence is an overt correction. Implicit negative evidence can take the form of either a communication breakdown or a recast. While Long and Robinson's taxonomy of negative evidence clearly defines recasts as an implicit type of negative evidence, other scholars argue that this may not necessarily be true in all instructional contexts (Ellis \& Sheen, 2006; Lyster \& Mori, 2006).

In the present study, feedback is an umbrella term which includes a variety of techniques ranging from the most explicit to the most implicit end of the continuum. The operational definition of feedback in the present study is a teacher's or interlocutor's reaction which points out the incorrectness of the learner's utterance occurring in both naturalistic environments (i.e., in conversational interaction) and instructed environments (i.e., in the classroom).

The distinction among types of evidence has theoretical importance for language acquisition. It is not difficult to understand that positive evidence is the most obviously necessary requirement for learning since one must be exposed to a set of grammatical sentences in order for learning to take place. However, the role of negative evidence in second language acquisition has continued to be a controversial issue over the past three decades. The evolution of the evidence as well as the input versus output debate in further detail below.

\subsubsection{Student Uptake/Repair}

In addition to the various types of second language acquisition feedback, the literature refers to the terms "uptake," which is a response by a student to the feedback provided after an error has been made and "repair," which refers to the effectiveness of a particular feedback. Both of these terms will be discussed in this section. Uptake has been investigated by researchers for a long time, including studies by Chaudron (1977), Ellis, Basturkmen, and Loewen (2001) and Lyster and Ranta (1997). Chaudron (1977) was one of the first researchers to refer to the term "uptake." Chaudron (1977) suggested evaluating the effectiveness of feedback in language classrooms based on the number of times students respond to feedback with correct responses. Later Lyster and Ranta (1997) defined uptake as the immediate student response to teacher feedback and the reaction in terms of the information regarding the learner's performance. Lyster and Ranta (1997) expanded Chaudron's definition by dividing learners uptake into two categories: "repair" and "needs repair" (p. 49) The term repair as defined by Lyster and Ranta (1997), indicates a successful correction of the wrong utterance in response to teacher's feedback. The term needs repair, on the other hand, indicate unsuccessful student reaction to the teacher's feedback in terms of correcting the wrong utterance (Lyster \& Ranta, 1997). Needs Repair can lead to the provision of additional feedback to facilitate successful student repair (Lyster \& Ranta, 1997).

Lyster and Ranta (1997) went further in their classification of repair and classified it further into two categories: self-initiated and other-initiated repair. Other-initiated repair is usually prompted by provision of some sort of feedback to the learner. The feedback can be provided by either a teacher or other students (peer feedback) in response to an error. Lyster's and Ranta's definitions of student uptake, specifically repair and needs repair, were chosen for use in the study because they include the most detailed and comprehensive categorization of this type of student action.

Uptake is a very important part of the language acquisition process and as Loewen (2002) noted many researchers are interested in examining uptake and linking it to the language learning process. Ellis et al. (2001) also support this statement by suggesting that uptake might be one of the factors that add to language acquisition.

The debate over the role of feedback in second language learning has been well documented in the second language acquisition literature as well as various other disciplines, including psychology (De Bot, 1996), cognitive science (DeKeyser, 1998, 2001) and linguistics (Schwartz, 1993; White, 1987). Researchers' views 
vary to a great extent regarding the types evidence provided by feedback, their classification, as well as their role in the development of specific domains of a second language.

Underlying these different views are diverse theoretical stances regarding the role of negative evidence and positive evidence (Gass, 2003), input and output (Krashen, 1982, 1985; Swain, 1985, 1995), and explicit and implicit learning (Dekeyser, 2001; Ellis, 1994; Schmidt, 1990, 1995) in SLA, which reflect the researchers' academic background and the research context from which they come.

This paper begins by reviewing linguistic concepts in the discussion of general mechanisms of second language acquisition relevant to the study of feedback. Following this review, issues specifically related to feedback classification and efficacy in the larger picture of second language learning process are raised. Finally, the discussion of different theories and hypotheses that are conductive to the role of corrective feedback in second language learning is presented.

\subsection{Krashen's Input Hypothesis}

The Input Hypothesis put forward by Krashen $(1982,1985)$ dismisses all traditional classroom interventions (e.g. Grammar teaching and error correction) and the role of negative evidence in language learning. Krashen (1982) has claimed that all second language learners need to acquire language is exposed to sufficiently rich comprehensible input; that knowledge of consciously learned language is distinct from unconsciously acquired language in representation; that only the latter type of knowledge can be developed in spontaneous language use and, furthermore, that there can be no interaction between "learning" and "acquisition." The non-interface position states that learned knowledge can never become acquired knowledge.

However other linguistic theories challenged Krashen's Input Hypothesis which both emphasizes the role of input and positive evidence in language learning. For example, White (1987) points out the importance of feedback, particularly as a source of negative evidence to indicate the inadequacy of learners' inter-language system, and suggests that positive alone is insufficient in second language acquisition. She further proposes that it is negative evidence triggered by incomprehensible input that becomes the impetus for learners to recognize their inadequate rule system, especially when they are required to go from a broader grammar (super set) to a narrower grammar (subset).

\subsection{Swain's Output Hypothesis}

Swain's $(1985,1995)$ Output Hypothesis challenges the traditional assumption that input is the only necessary requirement for second language acquisition, and that output is only the end product of second language acquisition that does not have any significant function in language acquisition processes (e.g., Krashen, 1985). From her research experience in French immersion context, Swain found that despite years of exposure to sufficiently rich comprehensible input in communicative classrooms, students lacked grammatical in terms of morphology and syntax (Harley \& Swain, 1984; Light \& Spada, 1994). She therefore argued that comprehensible input alone is not enough for learners to produce grammatical and error-free utterance. Furthermore, one of the most important reasons for promoting output as a means to improve second language learning is that when learners experience communication difficulties, they need to be pushed into making their output more precise and appropriate.

In general, the importance of output in learning may be construed in terms of the cognitive processes triggered by output and learners' active engagement in these processes. As Gass, Mackey, and Pica (1998) pointed out, it is the necessity for learners to engage in syntactic processing to strive words comprehensibility rather than comprehension of interlocutor input that may play a pivotal role in the acquisition process. It is also claimed that producing the target language may serve as "the trigger that forces the learner to pay attention to the means of expression needed in order to successfully convey his or her own intended meaning" (Swain, 1985, p. 249). Furthermore, Swain attributes considerable importance to corrective feedback, in effect associating the inadequacy of feedback as well as the inadequacy of pushed output with students' poor performance in grammatical accuracy in immersion classrooms.

Since the Output Hypothesis was first proposed, Swain has refined her hypothesis and specified the following four functions of output (Swain, 1993, 1995). First, output has a fluency function which provides learners with opportunities for developing speedy access to their existing second language knowledge in the actual use of grammar in meaningful contexts. Second, output has a hypothesis-testing function. In the process of producing output, learners are able to form and test their hypotheses about the comprehensibility and linguistic accuracy of their utterances in response to feedback obtained from their interlocutors. Third, output has a meta-linguistic function. It is claimed that "as learners reflect upon their own target language use, their output serves a 
meta-linguistic function, enabling them to control and internalize linguistic knowledge" (Swain, 1995, p. 126). In other words, output processes enable learners to reflect upon their use of the target language and consolidate their linguistic knowledge about the grammatical features of which they already have declarative knowledge. Reflection on language may enhance their awareness of forms, rules, and form-function mapping in a meaning context. Finally, output serves as a noticing function. Namely, in producing the target language, "learners may notice a gap between what they want to say and what they can say, leading them to recognize what they do not know, or know only partially" (Swain, 1995, pp. 125-126). The recognition of problems may then prompt the learners to selectively attend to the relevant information in the input, which will trigger their inter language development.

In summary, Swain's Output Hypothesis claims that output can, under certain conditions, promote language acquisition by allowing learners to invite feedback from interlocutors and teachers which informs them of the comprehensibility and well-formed of their inter language utterances, also allowing them to move beyond semantic processing to syntactic processing. It is this syntactic processing that is believed to be an important element in the underlying second language acquisition mechanism.

\subsection{Psycho Linguistic Rationale for the Output Hypothesis}

The widely held view on the role of output in second language acquisition has generated an increase in empirical investigations (Ellis \& He, 1999; Kowal \& Swain, 1994; Izumi \& Bigelow, 2000, 2001) as well as in theoretical discussion (de Bot, 1996; Izumi, 2003).

Taking the information processing approach as the starting point, de Bot (1996) argues that output serves an important function in second language acquisition, specifically because it can generate highly specific input that the cognitive system needs in order to build a coherent set of knowledge. It is also claimed that from an information processing point of view, output plays a direct role in the process of turning declarative knowledge into procedural knowledge. Furthermore, de Bot (1996) argues that when the learner's output does not match the correct form, negative feedback will allow the learners to pay attention temporarily to language form instead of meaning, which could hamper the registration of the erroneous form in memory. In other words, on the one hand, output invites feedback that promotes noticing. On the other hand, feedback plays an indispensable role in pushing learners to produce grammatically more accurate output, which may consolidate already-learned knowledge of the rules, enhance form-meaning mapping, or trigger faster access to the already-learned structure to develop automaticity.

Interlocutors' feedback may also create the condition for cognitive comparison that enables learners to notice the gap between their inter language output and the target language input (Izumi, 2003). In a word, output and feedback are interrelated constructs that allow learners to selectively attend to useful information in the input and to modify their ill-formed utterances, which are considered important processes in second language learning. The role of output may thus be seen as facilitating the process of input becoming intake.

\subsection{Attention, Awareness, and the Noticing Hypothesis}

The debate over positive evidence and negative evidence as well as input and output reflects one of the most controversial issues in applied linguistics, which concerns the role of conscious and unconscious processes in second language learning. On the one hand, there are many who believe that conscious understanding of the rule of the target language is necessary if learners aim to produce correct forms and use them in appropriate contexts. In this view, errors are the result of not knowing the rules of the target language, forgetting them, or not playing attention (Schmidt, 1990). Others firmly believe that language learning is an essentially unconscious process (e.g., Krashen, 1985). If second language learning were truly an unconscious process, then all second language learners should learn the language equally well in a rich second language environment.

\subsection{Schmidt's Noticing Hypothesis}

Drawing on data from the study by Schmidt and Frota (1986), Schimidt found that neither of the aforementioned two accounts could explain his own experience in learning Portuguese. Journal notes indicated that the forms he actually used were those he noticed people saying to him. Also, he found that a particular verb form that had been taught did not guarantee that it would appear in his output. Presence and frequency of input did not account for what was actually learned. Furthermore, he found that only the linguistic forms that he noticed were incorporated into subsequent language output. Schmidt (1990) maintains that this study provides strong evidence for a close connection between noticing and emergence in production. This claim develops into one of the most influential theories in the second language acquisition field- the Noticing Hypothesis.

In Schmidt's Noticing Hypothesis, two important constructs in cognitive psychology were raised. Attention and 
awareness are thought of as accounting for the creation of new knowledge and the modification of existing knowledge. Attention and awareness are related, but not synonymous, constructs that subsume various concepts.

Schmidt (1995) points out that it is difficult to distinguish between attention and awareness. Attention is a limited-capacity system that is sometimes associated with the differentiation between controlled and automatic activities. Tomlin and Villa (1994) divide attention into three components: detection (the cognitive registration of stimuli), alertness (general readiness to deal with the incoming stimuli), and orientation (the direction of resources to specific stimuli). They argue that detection is necessary for learning because " detection is the process by which particular exemplars are registered in memory and therefore could be made accessible to whatever the key processes are for learning" (pp. 192-193). However, they believe that awareness may enhance alertness and orientation, yet detection dose not necessarily imply awareness (Tomlin \& Villa, 1994, p. 198). It then follows that learning can take place without awareness but not without detection.

In contrast, Schmidt $(1990,1995)$ and Robinson $(1995,2003)$ argue for a critical role of awareness in learning, Robinson defines noticing as "detection with awareness and rehearsal in short memory" (1995, p. 318) and distinguishes noticing from detection that is not accompanied by awareness. According to Robinson (1995), noticing the form of input is the result of attention to the allocation leading to detection and rehearsal in short-term memory (STM), which is a necessary stage in SLA. Furthermore, what is noticed may be subsequently transferred to long-term memory (LTM). Noticing, therefore, plays an important role in illustrating the relationship between attention and memory.

Awareness is a subjective experience and commonly equated with consciousness (Schmidt, 1990). In his early work, Schmidt strongly opposes any unconscious learning, rejecting a dissociation of awareness and learning. It is posited that learners must consciously notice input in order for it to become intake. Schmidt differentiates two levels of awareness: awareness at the level of understanding (e.g., understanding the underlying rules of the linguistic form). It is awareness at the level of noticing that Schmidt claims is crucial for language learning, whereas awareness at the level of understanding is facilitate but not necessary for second language acquisition.

\subsubsection{Conditions for "Noticing" and the Role of Instruction}

By analyzing experimentally controlled studies, Schmidt (2001) claims that noticing is a necessary condition for storage of new forms, in other words, memory requires attention and awareness. He maintains that there are certain factors that determine what is noticed: 1) expectations, 2) frequency, 3) perceptual salience, 4) skill level, and 5) task demands. Schmidt proposes that, other things being equal, the more frequent a form is, the more likely it is to be noticed and then become integrated in the inter-language system. Presumably this is because repeated presentation may enhance the opportunity for a form to have been noticed at some time or other. If resources are variable and limited, then forms which are perceptually salient will have a greater chance of impinging on consciousness (Skehan, 1998).

In this respect, he argued, instruction may play an important role (Schmidt, 1990; Schmidt \& Frota, 1986). Instruction can work in a more complex way by making the less obvious aspects of the input more salient, so that when the learner does the extraction and focusing, he or she may be prompted to notice certain features or parts of the target language in the input, which will in turn determine which part of the input can become intake subsequently. In a sense, learning is still input-driven (since the input is not being transformed) but this way, instruction can allow the learner to choose what to prioritize in the input.

\subsection{The Interaction Hypothesis}

Advocates of recasts mostly draw on the Interaction Hypothesis proposed by Long (1996), who claims that conversational moves such as recasts and clarification requests provides learners with a primary source of language input which enables them to negotiate meaning in a natural flow of conversation while facilitating language development. Long's Interaction Hypothesis (1996) evolved from work by Hatch (1978) on the importance of conversation in the development of grammar, and from claims by Krashen (1985) that comprehensible input is a necessary condition for second language acquisition. In this view, during negotiation of meaning, when learners have communication breakdowns, they struggle to understand the interlocutors' utterance and to have the interlocutor understand their language, which leads to linguistic modification in a meaningful context. This allows them to both meaning and form at the same time.

In Long's (1996) updated interaction hypothesis, he has pointed out the role of negotiated interaction which elicits negative feedback (including recasts) in second language acquisition, "...negative feedback obtained in negotiation work or elsewhere may be facilitate of second language development" (p. 414). Recasts are highly valued as a feedback technique in this framework because they are assumed to provide both positive evidence 
and negative evidence by juxtaposing the correct and the incorrect utterances while keeping the meaning constant. In this way, they are thought to free up the learners' intentional resources which are limited and selective (Ammar \& Spada, 2006).

On the other hand, many studies have indicated that those conversational moves should be classified as negotiation of meaning, since they may only provide learners and their interlocutors with some communicative strategies that facilitate comprehension instead of focusing on the accuracy of form (e.g., Lyster \& Ranta, 1997; Pica, Young, \& Doughty, 1987). Furthermore, Lyster (2004b) claims that there is little direct evidence that actually associates conversational moves used in negotiation of meaning with second language development. In addition, he questions the feasibility of negotiation of meaning in classroom settings where "... mutual comprehension of inter-language forms reduces the need to negotiate for meaning" (p. 323).

An alternative theoretical framework for explaining is the information processing theory adapted from skill acquisition theory in cognitive psychology (de Bot, 1996; Dekeyser, 1998; Hulstijn, 1990; Lyster, 2004b). In the information processing framework, the role of feedback is prominent, since the procedures of rule-based declarative representations results from practice and feedback (Lyster, 2004b), which enables learners to restructure their inter-language. It is argued that without systematic feedback or other instructional interventions, inter-language representations can become fossilized and reach a development plateau. The information processing theory has been derived from Anderson's Adaptive Control of Thought (ACT) theory.

\subsection{Anderson's ACT Theory}

Anderson's adaptive control of thought (ACT) is a well-known general theory of skill acquisition which has stemmed from cognitive psychology (Anderson, 1983; 1985). ACT Theory has been adopted by several second language researchers (de Bot, 1996; DeKeyser, 1998; Hulstijn, 1990; Lyster, 2004b) to explain processes of second language acquisition in particular. The information processing theory in second language acquisition assumes that language learning is a special case of skill acquisition which involves a gradual transition from declarative knowledge to procedural knowledge. Declarative knowledge (knowledge of "that") refers to consciously held, skill-relevant knowledge that is described or factual knowledge. Procedural knowledge (knowledge of "how") is knowledge evident in a person's behavior but which the person is not consciously aware of and hence cannot describe in words (DeKeyser, 1998).

ACT Theory maintains that, initially, the execution of a cognitive skill involves retrieving and using declarative knowledge which requires a great deal of learners' limited attention capacity. This is called controlled information processing. Then, through a process of procedural knowledge (the transition from declarative knowledge to procedural knowledge), which involves passing from a cognitive stage where learners use declarative knowledge extensively, and an associate phase where rules are applied repeatedly in a consistent manner, learners gradually arrive at an autonomous stage where explicit knowledge of rules is no longer necessary. In this stage, learners may lose the declarative knowledge (although this is not necessarily the case, DeKeyser, 1998) but still can perform the task in a fast, coordinated fashion.

The information-processing model obviously has its strength in distinguishing two knowledge types and the developmental stages in language acquisition. However, since this model stems from cognitive psychology and applies to general skill acquisition rather than language per se, it inevitably has limitations in according for all aspects of the language acquisition process. For example, this model is established on the view that the acquisition of language is a rule-based system has been challenged by a number of scholars (Skehan, 1998). There has been a debate regarding representation system in second language acquisition, both in the linguistic and psycho-linguistic literature between proponents of a rule-based system (Reber, 1989) and advocates of what Skehan called "exemplar-based systems", i.e. Accumulations of large numbers of formulaic items (such as the item-based theory proposed by Logan, 1988).

\section{The "WCF Is Ineffective" Hypotheses}

\subsection{Principles of Universal Grammar}

Beginning in the early 70s, however, language acquisition research started shedding doubts on the behaviorist model of language learning and teaching and on the role and efficacy of formal grammar instruction and corrective feedback in both native language and L2 learning. Arguments against a focus on form, in their strongest version, are presented by researchers like Krashen (1985), Hammond (1988) and Schwartz (1993). Hammond, for instance, claims that error correction is of "no value" (Hammond, 1988, p. 414) in speeding up L2 acquisition. Indeed, some applied linguists posit that error correction can be harmful and should be avoided, since it may activate the "affective filter" by raising the students' level of anxiety which, in turn, prevents the 
learner from actually acquiring communicative ability. Supporters of this view usually hold that L1 as well as L2 acquisition is governed by principles of universal grammar and that grammatical structure are acquired in a certain predetermined order, regardless of sequence of instruction or amount of corrective feedback.

The acquisition of a grammatical structure is a gradual process, not a sudden discovery as the intuitive view of correction would imply. The acquisition of lexical and morphological knowledge involves subtle learning processes. To be effective, correction must address these processes, not just passing information from teachers to students. WCF only deals with the surface manifestations of grammar, ignoring the processes by which underlying systems develops.

UG (Chomsky, 1981) is the theory of the initial state of human language faculty, linguistics under generative approach are concerned with the states of language faculty, which are believed to be some array of cognitive traits and capacities, a particular component of human mind/brain. The language has an initial state, genetically determined, which passes through a series of states in early childhood and reaches a relatively stable steady state that undergoes little subsequent change, apart from the lexicon.

\subsection{Pseudo-Learning}

Inter-language develops through subtle, poorly understand processes. It would be surprising if all types of teaching/learning were consistent with them. Rather, some will be fail to affect the underlying, developing system, instead producing only a superficial and possibly transient form of knowledge, with little value for actual use of the language. Such learning would be better described as pseudo-learning. The diversity of theoretical views represented by this group of researchers makes it clear that the concern is pervasive. This concern is supported by research that showed learners had acquired good intellectual knowledge of the target language but had no ability to use this ability (e.g., Kadia, 1988). In related work, follow-up testing and observation showed that knowledge which students had apparently acquired actually disappeared in a matter of months, probably indicating that the teaching had produced nothing more than pseudo-learning. Consider grammar correction in this approach, if the practices have an effect on the learner, but the effect is simply to produce pseudo-learning, and then it has little or no value.

\section{Conclusion and Discussion}

While feedback has provided a pivotal role to play in the writing classroom, much of the exiting literature has highlighted its limited impact on student learning. Whether it is teacher feedback, self-/ peer feedback or computer-mediated feedback, there is no yet conclusive evidence about its efficacy across different contexts. It is therefore not surprising that feedback has remained one of the most vibrant research topics in writing.

Although feedback is closely tied to the work of teachers, the majority of feedback studies have been conducted outside pedagogical contexts, which are referred to as "non-contextual and nonsocial". In recent years, researchers have called for a greater emphasis on context in feedback research: research focuses on feedback within the whole context of learning and on the learner's role in interpreting and using feedback. Ellis (2007) suggests that research should explore the interactive and contextual nature of response or work that considers response in relation to the writing outcomes. Researchers' cognizance of feedback as a social act and a real-world practice has resulted in an increasing interest in teacher's feedback practices in the real classroom, as well as student's perceptions of and reactions to teachers' feedback practices in specific classroom context.

\section{Acknowledgments}

The author wishes to thank the anonymous reviewers and the editor for their helpful comments.

\section{References}

Ammar, A., \& Spada, N. (2006). One size fits all? Recasts, prompts, and L2 learning. Studies in Second Language Acquisition, 28, 543-574.

Anderson, J. (1983). The architecture of cognition. Cambridge, MA: Harvard University Press.

Anderson, J. (1985). Cognitive psychology and its implications (2nd ed.). New York: W.H. Freeman and Co.

Bangert-Drowns, R. L., Kulik, C. C., Kulik, J. A., \& Morgan, M. T. (1991). The instructional effect of feedback in test-like events. Review of Educational Research, 61(2), 213-238.

Bitchener, J. (2008). Evidence in support of written corrective feedback. Journal of Second Language Writing, $17,102-118$.

Carroll, S. (2001). Input and evidence: The raw material of second language acquisition. Philadelphia: John Benjamins. 
Chandler, J. (2003). The efficacy of various kinds of error feedback for improvement in the accuracy and fluency of L2 student writing. Journal of Second Language Writing, 12, 267-296.

Chaudron, C. (1977). A descriptive model of discourse in the corrective treatment of learners' errors. Language Learning, 27, 29-46.

Chaudron, C. (1988). Second language classrooms. Cambridge: Cambridge University Press.

Chomsky, N. (1981). Lectures on Government and Binding. Dordrecht Foris.

De Bot, K. (1996). The psycholinguistics of the output hypothesis. Language Learning, 46, 529-555.

Dekeyser, R. (1993). The effect of error-correction on L2 grammar knowledge and oral proficiency. Modern Language Journal, 77, 501-514.

Dekeyser, R. (1998). Beyond focus on form: Cognitive perspective on learning and practicing second language grammar. In C. Doughty, \& J. Williams (Eds.), Focus on form in classroom second language acquisition (pp. 42-63). New York: Cambridge University Press.

Dekeyser, R. (2001). Automaticity and automatization. In P. Robinson (Ed.), Cognition and second language instruction (pp. 125-151). New York: Cambridge University Press.

Egi, T. (2007a). Interpreting recasts as linguistic evidence: The roles of linguistic target, length, and degree of change. Studies in Second Language Acquisition, 29, 511-537.

Ellis, R. (1994). The study of second language acquisition. Oxford: Oxford University Press.

Ellis, R. (2007). The differential effects of corrective feedback on two grammatical structures. In A. Mackey (Ed.), Conversational interaction in second language acquisition: A collection of empirical studies (pp. 339-360). Oxford: Oxford University Press.

Ellis, R., \& He, X. (1999). The roles of modified input and output in the incidental acquisition of word meaning. Studies in Second Language Acquisition, 21, 285-301.

Ellis, R., \& Sheen, Y. (2006). Re-examining the role of recasts in L2 acquisition. Studies in Second Language Acquisition, 28, 575-600.

Ellis, R., Basturkmen, H., \& Loewen, S. (2001). Learner uptake in communicative ESL lessons. Language Learning, 51, 281-318.

Ellis, R., Loewen, S., \& Erlam, R. (2006). Implicit and explicit corrective feedback and the acquisition of L2 grammar. Studies in Second Language Acquisition, 28, 339-368.

Ferris, D. R. (1999). The Case for Grammar Correction in L2 Writing Classes: A Response to Truscott (1996). Journal of Second Language Writing, 8(1), 1-11.

Ferris, D. R. (2002). Treatment of error in second language student writing. Ann Arbor, MI: University of Michigan Press.

Ferris, D. R. (2003). Response to student writing: Implications for second language students. New York: Routledge.

Ferris, D. R. (2010). Second language writing research and written corrective feedback in SLA: Intersections and practical applications. Studies in Second Language Acquisition, 32(2), 181-201.

Ferris, D. R. (2012). Treatment of error in second language student writing. Ann Arbor, MI: University of Michigan Press.

Ferris, D. R., \& Helt, M. (2000). Was Truscott? New evidence on the effects of error correction in L2 writing classes. Paper presented at the American Association of Applied Linguistics Conference.

Ferris, D. R., \& Roberts, B. (2001). Error feedback in L2 writing classes: How explicit does it need to be? Journal of Second Language Writing, 10(3), 161-184.

Ferris, D., \& Hedgcock, J. S. (1997). Teaching ESL composition: Purpose, process, \& practic. Mahwah, NJ: Lawrence Erlbaum Associates.

Gass, S. M. (1997). Input, interaction and the second language learner. Mahwah, NJ: Lawrence Erlbum.

Gass, S. M. (2003). Input and interaction. In C. Doughty, \& M. Long (Eds.), The handbook of second language acquisition (pp. 224-255). Malden, MA: Blackwell Publishing.

Gass, S., Mackey, A., \& Pica, T. (1998). The role of Input and Interaction in Second Language Acquisition: 
Introduction to the Special Issue. The Modern Language Journal, 82, 299-305.

Hammond, R. M. (1988). Accuracy versus Communicative Competency: The Acquisition of Grammar in the Second Language Classroom. Hispania, 71, 408-417.

Harley, B., \& Swain, M. (1984). The interlanguage of immersion students and its implications for second language teaching. In A. Davies, C. Criper, \& A. Howatt (Eds), Interlanguage (pp. 291-311). Edinburgh: Edinburgh University Press.

Hatch, E. (1978). Discourse analysis and second language acquisition. In E. Hatch (Ed.), Second language acquisition: A book of readings (pp. 401-475). Rowley, MA: Newbury House.

Hattie, J., Biggs, J., \& Purdue, N. (1996). Effects of learning skills interventions on student learning: A meta-analysis. Review of Educational Research, 66(2), 99-136.

Henderickson, J. M. (1978). Error correction inforeign language teaching: Recent theory, research and practice. The Modern Language Journal, 62(8), 387-398.

Hulstijn, J. (1990). A comparison between the information processing and analysis approaches to language learning. Applied Linguistics, 11, 30-45.

Hulstijn, J., \& De Graaff, R. (1994). Under what conditions does explicit knowledge of a second language facilitate the acquisition of implicit knowledge? A research proposal. AILA Review, 11, 97-112.

Izumi, S. (2003). Comprehension and production processes in second language learning: In search of the psycholinguistic rationale of the output hypothesis. Applied Linguistics, 24, 168-196.

Izumi, S., \& Bigelow, M. (2000). Does output promote noticing and second language acquisition? TESOL Quarterly, 34, 239-278.

Izumi, S., \& Bigelow, M. (2001). Methodological and theoretical issues in testing the effects of focus on form. TESOL Quarterly, 35, 181-189.

Kadia, K. (1988). The effect of formal instruction on monitored and spontaneous naturalistic inter language performance: A case study. TESOL Quarterly, 22, 509-515.

Kepner, C. G. (1991). An experiment in the relationship of types of written feedback to the development of second language writing skills. Modern Language Journal, 75, 305-313.

Kowal, M., \& Swain, M. (1994). Using collaborative language production tasks to promote students' language awareness. Language Awareness, 3, 73-93.

Krashen, S. (1982). Principles and practice in second language acquisition. Oxford: Pergamon.

Krashen, S. (1985). The input hypothesis: Issues and implications. New York: Longman.

Krashen, S. D. (1984). Writing: Research, theory, and applications. Oxford: Pergamon Institute of English.

Kulhavy, R. W. (1977). Feedback in written instruction. Review of Educational Research, 47(2), 211-232.

Kulhavy, R. W., \& Stock, W. A. (1989). Feedback in written instruction: The place of response certitude. Educational Psychology Review, 1(4), 279-308.

Lalande, J. F. (1982). Reducing composition errors: An experiment. Modern Language Journal, 66, 140-149.

Lightbown, P. (1998). The importance of timing in focus on form. In C. Doughty, \& J. Williams (Eds.), Focus on form in classroom second language acquisition (pp. 177-196). Cambridge: Cambridge University Press.

Lightbown, P., \& Spada, N. (1994). An innovative program for primary ESL in Quebec. TESOL Quarterly, 28 , 563-573.

Loewen, S. (2002). The occurrence and effectiveness of incidental focus on form in meaning-focused ESL lessons (Unpublished Doctoral Thesis). The University of Auckland, Auckland, New Zealand.

Logan, G. (1988). Towards an instance theory of automatisation. Psychological Review, 95, 492-527.

Long, M. H. (1996). The role of the Linguistic Environment in Second Language Acquisition. W. C. Ritchie, \& T. K. Bhatia (Eds.), Handbook of Second Language Acquisition. San Diego, CA: Academic Press.

Long, M., \& Robinson, P. (1998). Focus on Form: Theory, research, and practice. In C. Doughty, \& J. Williams (Eds.), Focus on form in classroom second language acquisition (pp. 15-41). New York: Cambridge University Press.

Lyster, R. (1998a). Recasts, repetition, and ambiguity in L2 classroom discourse. Studies in Second Language 
Acquisition, 20, 51-81.

Lyster, R. (1998b). Negotiation of form, recasts, and explicit correction in relation to error types and learner repair in immersion classrooms. Language Learning, 48, 183-218.

Lyster, R. (2002). Negotiation in immersion teacher-student interaction. International Journal of Educational Research, 37, 237-253.

Lyster, R. (2004a). Research on form-focused instruction in immersion classrooms: Implications for theory and practice. French Language Studies, 14, 321-341.

Lyster, R. (2004b). Differential effects of prompts and recasts in form-focused instruction. Studies in Second Language Acquisition, 26, 399-432.

Lyster, R., \& Mori, H. (2006). Interactional feedback and instructional counterbalance. Studies in Second Language Acquisition, 28, 269-300.

Lyster, R., \& Ranta, L. (1997). Corrective feedback and learner uptake. Studies in Second Language Acquisition, 19(1), 37-66.

MacKey, A., Gass, S., \& McDonough, K. (2000). How do learners perceive implicit negative feedback? Studies in Second Language Acquisition, 22, 471-497.

McNulty, A. (2007). A study of corrective feedback and uptake patterns as observed in four foreign language classrooms at selected Mid-Western Public Schools (Unpublished Doctoral Thesis). University of Nebraska.

Philp, J. (2003). Constraints on "noticing the gap": Non-native speakers' noticing of recasts in NS-NNS interaction. Studies in Second Language Acquisition, 25, 99-126.

Pica, T., Young, R., \& Doughty, C. (1987). The impact of interaction on comprehension. TESOL Quarterly, 21, 737-758.

Polio, C., Fleck, C., \& Leder, N. (1998). If I only had more time: ESL learners' changes in linguistic accuracy ones say revisions. Journal of Second Language Writing, 7, 43-68.

Pressey, S. L. (1926). A simple device which gives tests and scores- and teaches. School and Society, 23, 373-376.

Reber, A. (1989). Implicit learning and tacit knowledge. Journal of Experimental Psychology: General, 118, 219-235.

Robb, T., Ross, S., \& Shortreed, I. (1986). Salience of feedback on error and its effect on EFL writing quality. TESOL Quarterly, 20, 83-93.

Robinson, P. (1995). Review article: Attention, memory and the "noticing" hypothesis. Language learning, 45, 283-331.

Robinson, P. (2003). Attention and memory in SLA. In C. Doughty, \& M. Long (Eds.), The handbook of second language acquisition (pp. 631-678). Oxford: Blackwell.

Russell, J., \& Spada, N. (2006). The effectiveness of corrective feedback for second language acquisition: A meta-analysis of the research. In J. Norris, \& L. Ortega (Eds.), Synthesizing research on language learning and teaching (pp. 133-163). Amsterdam: John Benjamins.

Schmidt, R. (1990). The role of consciousness in second language learning. Applied Linguistics, 11, 129-158.

Schmidt, R. (1995). Attention and awareness in foreign language learning. Honolulu, HI: University of Hawaii Press.

Schmidt, R. (2001). Attention. In P. Robinson (Ed.), Cognition and second language instruction (pp. 3-32). Cambridge: Cambridge University Press.

Schmidt, R., \& Frota, S. (1986). Developing basic conversational ability in a second language: A case study of an adult learner of Portguese. In R. Day (Ed.), Talking to learn: Conversation in second language acquisition (pp. 237-326). Rowley, MA: Newbury House.

Schwartz, B. (1993). On explicit and negative data effecting and affecting competence and linguistic behavior. Studies in Second Language Acquisition, 15, 147-163.

Semke, H. (1984). The effects of the red pen. Foreign Language Annals, 17, 195-202.

Sheen, Y. (2004). Corrective feedback and learner uptake in communicative classrooms across instructional 
settings. Language Teaching Research, 8, 263-300.

Sheen, Y. (2006). Exploring the relationship between characteristics of recasts and learner uptake. Language Teaching Research, 10, 361-392.

Sheen, Y. (2007). The effect of Focused Written Corrective Feedback and Language Aptitude on ESL Learners' Acquisition of Articles. TESOL Quarterly, 41, 255-283.

Skehan, P. (1998). A cognitive approach to language learning. Oxford: Oxford University Press.

Swain, M. (1985). Communicative competence: Some roles of comprehensible input and comprehensible output in its development. In S. Gass, \& C. Madden (Eds.), Input in second language acquisition (pp. 235-253). Rowley, MA: Newbury House.

Swain, M. (1993). The output hypothesis: Just speaking and writing aren't enough. The Canadian Modern Language Review, 50, 158-164.

Swain, M. (1995). Three Functions of Output in Second Language Learning. Principles and Practice in Applied Linguistics: Studies in Honor of H. G. Widdowson. Oxford: Oxford University Press.

Tomlin, R. S., \& Villa, V. (1994). Attention in cognitive science and second language acquisition. Studies in Second Language Acquisition, 16, 183-203.

Trofimovish, P., Ammar, A., \& Gatbonton, E. (2007). How effective are recasts? The role of attention, memory, and analytic ability. In A. Mackey (Ed.), Conversational interaction in second language acquisition: A collection of empirical studies (pp. 171-195). Oxford: Oxford University Press.

Trowbridge, M. H., \& Cason, H. (1932). An experimental study of Thorndike's theory of learning. Journal of General Psychology, 7, 245-258.

Truscott, J. (1996). The case against grammar correction in L2 writing classes. Language Learning, 46, 327-369.

Truscott, J. (1999). The case for "The case against grammar correction in L2 writing classes": A response to Ferris. Journal of Second Language Writing, 8(2), 111-122.

White, L. (1987). Against comprehensible input: The input hypothesis and the development of L2 competence. Applied Linguistics, 8, 95-110.

Yang, Y. (2008). Corrective feedback and Chinese learner's acquisition of English past tense (Unpublished Doctoral Thesis). McGill University.

\section{Copyrights}

Copyright for this article is retained by the author(s), with first publication rights granted to the journal.

This is an open-access article distributed under the terms and conditions of the Creative Commons Attribution license (http://creativecommons.org/licenses/by/3.0/). 